in a much expanded form under the title, Das Aliendmahl in den zuci ersten Jahrhunderten nach Christus (Giessen : J. Ricker; price M.I.80). The work deserves study as a careful and able examination of the Scripture and other early evidence as to the original character of the Eucharist, and for the convincing way in which the author traces the transformation of the sacramental into the sacrificial notion.

Possessors of Dr. Adolf Erman's Aegyptische Grammatik will rejoice to have now put into their hands the same author's Aegyptisches Glossar (Berlin : Reuther \& Reichard; price MI. 13), which contains the more frequently occurring words in the Egyptian language. In addition to the excellence of the contents, we would specially commend the typography, which leaves nothing to be desired.

It has so often been our pleasant duty to commend in the highest terms Messrs. C. A. Schwetschke \& Sohn's Theologischer Jahresbericht, that on the present occasion we shall content ourselves with merely noting the issue of the second and third 'Abteilungen' of the current issue. These contain respectively the Old Testament and the New Testament literature for the year I903. The one is edited by Volz, the other by Holtzmann, Knopf, and Weiss.

\title{
$\longrightarrow \cdot \dot{\square}$

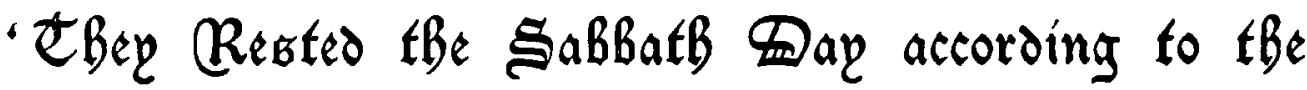 Commanoment.'
}

IULE XIIII. 56.

By the Rev. H. S. Cronix, B.D., Fellow and Dean of Trinity Hall, Cambridge.

St. Matthew and St. Mark contain no explicit mention of the observance of the Sabbath on the morrow of our Lord's death. They say, indeed, that the first day of the week saw renewed activity on the part of His followers, and the way in which they allude to this activity implies the rest of the day before; but it is left to St. Luke, the Gentile, to draw attention formally and expressly to this obedience of theirs to the command of the dispensation in which they had been nurtured, and whose glory was being done away; it is left to him to connect in so many words their rest on this occasion with the old Jewish commandment enjoining rest, and to emphasize the fact that they were not only loyal to the old even to the end, but that such loyalty lay consciously at the root of their inaction during the period that our Lord lay in the tomb. If they rested on the Sabbath, they rested according to the commandment.

Of St. Luke's readers-Gentiles though most of them were, and even in many cases converts from heathenism - few were altogether unacquainted with the institution of the Sabbatin and of the great part it played in the life of their Jewish neighbours. The Dispersion was everywhere; and courted notice as much by its energy and its ability as by its turbulence, its exclusiveness, and the peculiarities of its character and institutions. The least observant and the most unsympathetic subject of the Roman Empire could hardly have failed to notice that certain of his fellow-subjects-and those men not easily ignored -deliberately abstained from working on one day in the week. The intercourse of daily life, and especially the intercourse of trade, would make such ignorance impossible for nearly all, while the magistrate was so well aware of how things stood that he had decided that it was better policy to forgo the service in the army of a proportion of the population than to employ men who refused to work one day in seven, and who replied to coercion in a manner which had more than once strained nearly to breaking the strength even of the empire.

But though neighbours could notice, and satirists deride, and statesmen accept the institution of the Sabbath, it was reserved for those in sympathy with Judaism to appreciate its importance for the religious life of the world. Many of St. Luke's readers-as, perhaps, St. Luke himself 
-had in some way or other reached Christianity through Judaism; to each of these, in varying degrees and according to their varying powers of perception, and in their measure also to each of the heathen converts, the mention of the Sabbath in this connexion must have appeared full of significance. Of its early history and of its relation to kindred Semitic institutions, they certainly were ignorant. Had they known from what unpromising beginnings it took its rise, and what different shapes it had assumed in less careful or less worthy hands, they would have gained fresh views of God's manner of dealing with the world; and though they might have felt that Israel could have done better by its trust, they could not have failed also to see how great spiritual oversight on the part of Jehovah, and how great spiritual insight on the part of Israel was implied for the Sabbath to have become in Israel's hands the beneficent institution that it was.

Yet from the Jewish scriptures, or from the tradition of the nation, or from personal experience, the devout Israelite, the devout proselyte, and the devout Christian could learn all that was essential to enable him to appreciate the part the Sabbath played at this crisis of the Christian Church. From Holy Scripture they could learn -and the teaching lay very much on the surfacethat it was intended to serve two purposes. 'Six days shalt thou do thy work,' says apparently the earliest of the laws which bear upon this subject, ' and on the seventh day thou shalt desist in order that thy ox and thy ass may rest, and that the son of thy maidservant and thy stranger may be refreshed.' The Israelite is 'to keep the Sabbath holy,' says what is perhaps a piece of later legislation, 'for it is a Sabbath unto Jehovah.' And so throughout the course of revelation, with varying promises for obedience and varying penalties for neglect, with varying emphasis and for varying reasons, this religious observance was enjoined in its two aspects on the faithful in Israel almost, we may say, as a test of loyalty to God. They were to rest from ordinary pursuits because God had rested on the seventh day; they were to let others rest because their nation had felt in Egypt the stress of unintermittent toil, and they were to make their rest complete by worship, because our heart is disquieted within us until we find our rest in God.

However much, in some respects, tradition may have failed to keep itself true to the Sabbath of revelation, it never faltered in its devotion to the institution itself. Its mistakes indeed were due to excess of zeal, to over-anxiety lest the commandment should be of no effect. But though excess of zeal produced formal regulations, which robbed the Sabbath of much of its usefulness to man, and obscured or strangled its spiritual teaching, the tradition never lost sight altogether of man's interest, or of the even higher purpose the Sabbath was meant to serve. On the contrary, it was careful to tell how through the slaughter of their comrades without resistance on the Sabbath day God had taught the Maccabees that the normal observance of the Sabbath must give way to the necessity of self-defence, and had preserved thereby not only the lives of the faithful but their continued witness to Himself. In order to the due worship of God, it not only allowed the priests in the temple to profane the Sabbath and be blameless, but it enjoined on them a double share of work.

But then, as always, it was from his own experience that the devout man learned the value and significance of this institution. The taking of rest is a practical confession of our need of rest, and involves a confession, conscious or unconscious, of our finiteness, which finds its reward in renewed strength and freshness. $\mathrm{He}$ who had humbled himself to such confession was exalted to clearer perception, juster criticism, and more effective action. And if the reward was great for him who merely rested, how much greater was it for him who rested knowing what he did, who spent the time, wrung from his finiteness, not merely in leaving things alone, but in throwing himself on the source of strength, the infinite power and love of God. Physically, the effect of the abstinence from work would be as great as ever; morally and spiritually, its effect for such a one would be increased a thousandfold. $\mathrm{He}$ had recognized in thought and deed his limitations; he had tried to ascertain what for him was possible and on what conditions; he had examined his conduct by the rule of God's commandments; he had confessed his failures, and had ascribed to its true cause his measure of success. Above all, he had learned to trust God. Time after time, as the period of rest came round, it must have found him engaged with things which touched him nearly, or which he thought imperiously to demand his interference. With rare exceptions he was wrong, 
and with rare exceptions he found the world in the end not worse but better for having had to do without him. He could, therefore, henceforth afford to face his limitations, for behind them stood the infinite God.

The lessons of experience being such as these, it is little wonder if -with significant changes of observance and interpretation-a weekly season of rest and devotion was retained in the Christian Church. The wonder is less if we take into account the effect on our Lord's immediate followers of the Sabbath of our text, the last true Sabbath of the Old Dispensation. In a writer of St. Luke's power, the explicit mention of its observance cannot be idle; its occurrence at this crisis was, he saw, of the utmost importance for the twelve: and, while the peculiar form the Sabbath had assumed made it the more effective then for the peculiar purpose it had to serve, its employment at all at such a time must have suggested to him new ideas of the wisdom of God's providence, of the value of routine, and of the value of the existence of a periodic day of rest.

Nothing can be harder than to estimate at its full the amount of stress which had fallen to the share of His immediate followers during the closing days of our Lord's life. The stress had begun as soon as they had crossed the Jordan and had joined the crowds, roused once more to enthusiasm by the season-it was the Passover; by the locality-it was the scene of Israel's first triumphs and of the activity of its latest prophet; and by the presence in their midst of Him whose mission that prophet had foretold. The beginning of the journey from Jericho to Jerusalem had seen the miracle, itself prophetic, which had restored the blind to sight; the close of it saw the crowds strewing their garments in Christ's way, plucking the branches from the trees, and greeting Him with cries of, 'Blessed be the King that cometh in the name of the Lord.' Small wonder if many thought the kingdom of God would immediately appear; small wonder if the apostles themselves desired to think so too.

At the height of their enthusiasm-enthusiasm which our Lord Himself had fostered-the crowds were dismissed. Again they had failed to take Him by force and make Him King. Again the apostles had been led almost to the brink of temptation and again led back. But either on the morrow, or when the crowds threatened no danger, our Lord again asserted His authority. The temple needed cleansing, and it was cleansed. His action roused the priests, but it did not attract the people. The apostles saw that $\mathrm{He}$ had refused the alliance of the crowds, had asserted the moral nature of $\mathrm{His}$ kingdom, and had further alienated and emboldened powerful foes. These soon showed their encouragement. Baffled by the sincerity of our Lord's wisdom, they betook themselves to force. Our Lord was seized, tried, condemned, and put to death; but not until $\mathrm{He}$ had once more told His disciples plainly what was about to come to pass, and not until one had betrayed Him, one had denied that he even knew Him, and all had forsaken Him and fled.

It was on men thus circumstanced that in God's providence the Sabbath dawned, men still in danger from those who had slain their Master, men disgraced in their own eyes and in the eyes of others by their desertion, men made desolate by the loss they had sustained. It prescribed for them how far they might go, it limited what they might do; left them in Jerusalem at the mercy of their foes; it condemned them to inactivity, face to face with their danger, their desolation, and their shame.

But inactivity was the very thing they needed most. The physical strain alone must have been intense. If on the eve of the betrayal the chosen three were heavy with sleep, what must have been the condition of them all when a night and a day of vigil, and danger, and grief, had come and gone? The apostles, moreover, had had their own ideas of what was going to happen, and had clung to those ideas right to the end. They had striven to ignore the plainest language to the contrary, or the most patent facts. They had seized on every symptom in the crisis which favoured their view, and had hoped even while our Lord was hanging on the cross that $\mathrm{He}$ would indeed come down and save Himself and them. The days had been for them days of expectation, of hope deferred, of gradual enlightenment as to their Master's purpose, of the obstinate thrusting from them conclusions which somehow they knew would triumph in the end; and our Lord's death left them stunned, as men are stunned who have deliberately hoped against hope, and found their hope deceive them.

Of their sorrow for their Master's loss, of their 
distress at their desertion of Him, of their apprehension for themselves, I need not speak. I need only point out that the Sabbath, with its restrictions as to travelling, now came to the rescue of their courage, and kept them at their posts.

When things have been long in the balance, and the blow has come at last, men are still reluctant to believe that it has come at all. Their very exhaustion favours incredulity, for it deadens pain and the power of perception, it suffers them to cheat themselves with hopes; as the exhaustion wears off, they seek a like relief in restlessness. The disciples had been slow to believe our I ord was to die; they might have been at least as slow to believe Him dead. The Sabbath, however, kept them quiet; it not only secured them time to think, but, by the removal of all distraction, made them think. And as in time conviction of the reality of His death became possible, it cut them off from every refuge from conviction. They had seen their Master crucified and put to death. With all reverence, in spite of the need of haste, certain of them had placed $\mathrm{His}$ body in the tomb. The Sabbath gave them time to realize that, and to have no doubt about it. Yet the Sabbath itself had intervened to make the burial in some sort incomplete. There is no mention at the time of formal lamentation, and the day after the Sabbath found the women still busy with what they had to do. It was as if the Sabbath said the death is real enough, but the death is not the end. It resolutely closed the door to illusions of self-will and folly; it never closed it to the hopes of wiser counsels and more disciplined illumination.
And these soon began to assert themselves; the apostles soon began to see that what had without doubt come to pass-had come to pass as Christ had said. He had divined the past better than they, and had forecnst the future more truly. He had said $\mathrm{He}$ would be given up- $\mathrm{He}$ had been given up: He had said $\mathrm{He}$ would be put to death-He had been put to death. He had said also that $\mathrm{He}$ would rise again,-will $\mathrm{He}$ also rise again?

And so the quiet of the Sabbath did its work; to tired minds and weary bodies it brought rest; with gentle pressure, the pressure of an eternal discipline, it kept the waverers true to their allegiance; it gave them the calmness which faces facts, and picks from a situation, apparently disastrous, its elements of hope and comfort; it compelled them, knowing that our Lord was dead, to attempt some answer to the questions which they had not even dared to ask before; it let them work out for themselves some clue to the meaning of the 'Rising from the Dead,' with which to anticipate and to welcome the news that Christ was risen.

But, while it lasted, it was an ordeal terrible in its intensity, and as searching as salutary and indispensable, an ordeal such as few men would have assigned to others, and none have dared for themselves. Yet for them, in their high calling, Divine wisdom chose it; to some extent we can perceive its purpose; and we marvel at the foresight which had ordained it for them from the time that God saw the world which $\mathrm{He}$ had made, that it was good, and the sons of God shouted for joy.

\section{Q}

\section{(phiposophe as Scientia Scientiarum.}

This, the latest work from the pen of Professor Flint, consists of two parts, one descriptive and theoretical, the other historical and critical. The

'Philosophy as Sirntia Scientiarmm, and a History of Classifications of the Sicnces. By Robert Flint, D.D., I.L.D., F.R.S.E., Corresponding Member of the Institute of France, Honorary Member of the Royal Society of Palermo, and Professor-Emeritus Edinburgh Unversity. Edinburgh : William Blackwood \& Sons. first part is a luminous statement of Dr. Flint's idea of Philosophy, of its function in human knowledge, and of its position as a whole, and of the parts of it which in their interrelations and in their relation to the whole make up the organism of philosophy. The second part impresses us with its vast learning, its clearness and accuracy of statement, and with its succinct and sometimes drastic criticism. Both in the statement of the attempts at classifications and in the critical examination of them the reader can see that reference is made to 